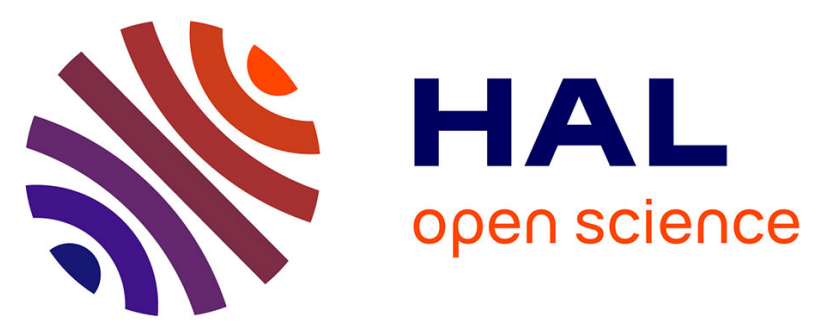

\title{
Improving Labor Productivity and Labor Elasticity at Multiproduct Japanese Cuisine Restaurant Introducing Cell-Production System
}

Takeshi Shimamura, Takeshi Takenaka, Syuichi Ohura

\section{To cite this version:}

Takeshi Shimamura, Takeshi Takenaka, Syuichi Ohura. Improving Labor Productivity and Labor Elasticity at Multiproduct Japanese Cuisine Restaurant Introducing Cell-Production System. 20th Advances in Production Management Systems (APMS), Sep 2013, State College, PA, United States. pp.11-17, 10.1007/978-3-642-41263-9_2 . hal-01451761

\author{
HAL Id: hal-01451761 \\ https://hal.inria.fr/hal-01451761
}

Submitted on 1 Feb 2017

HAL is a multi-disciplinary open access archive for the deposit and dissemination of scientific research documents, whether they are published or not. The documents may come from teaching and research institutions in France or abroad, or from public or private research centers.
L'archive ouverte pluridisciplinaire HAL, est destinée au dépôt et à la diffusion de documents scientifiques de niveau recherche, publiés ou non, émanant des établissements d'enseignement et de recherche français ou étrangers, des laboratoires publics ou privés.

\section{(ㄷ)(i)}

Distributed under a Creative Commons Attribution| 4.0 International License 


\title{
Improving Labor Productivity and Labor Elasticity at Multiproduct Japanese Cuisine Restaurant Introducing Cell-Production System
}

\author{
Takeshi Shimamura ${ }^{1,2}$, Takeshi Takenaka ${ }^{1}$, and Syuichi Ohura ${ }^{2}$ \\ ${ }^{1}$ Center for Service Research, National Institute of Advanced Industrial Science and \\ Technology, Tokyo, Japan \\ ${ }^{2}$ Ganko Food Service Co. Ltd., Osaka, Japan
}

Takeshi Shimamura, t-shimmura@aist.go.jp

\begin{abstract}
This study examined improvement of labor productivity and elasticity of labor hour on sales of a multiproduct Japanese cuisine restaurant. Conventionally, multiproduct restaurant operations include a line production system in the kitchen. Japanese chefs are assumed to be low-skilled workers with staff members supported by someone. A cell production system is introduced into a Japanese Cuisine restaurant to improve it. Results show that the cell production system improves both labor productivity and elasticity of labor hours because the system reduces fixed labor hours during less-busy times in the kitchen. To introduce the system, it is important to educate and train kitchen staff members because the system requires preparation of other staff members' food orders during idle time.
\end{abstract}

\section{Introduction}

In Japan, service industry organizations account for approximately $73 \%$ of Japanese GDP. Therefore, the industry plays important roles in the Japanese economy. The restaurant industry is one of the largest service industries: the industry hires approximately 4 million staff members. Sales revenues were approximately 277 billion dollars in 2011 [1][2].

Although the restaurant industry is a key industry, labor productivity is the lowest among service industries [3]. Moreover, food-service is a typically labor-intensive industry. Many reports have described characteristics of service products preventing service industries from improving labor productivity [4][5]. For instance, service products can not be stocked (intangibility). Therefore, service providers should produce service products at the same time that a customer orders it. The service industry "low productivity problem" is important not only for individual companies but also for the macro economy. As the market share of service industries increases [6],

adfa, p. 1, 2011.

(C) Springer-Verlag Berlin Heidelberg 2011 
productivity of the entire country will decrease accordingly. To resolve these problems, service industries must improve labor productivity.

The Japanese restaurant industry has introduced some innovative systems developed to enhance productivity in manufacturing enterprises [7]. For example, restaurants have adopted a central kitchen as a food factory to simplify cooking operations at stores [8][9][10]. Additionally, they have introduced information technology (e.g., POS system) to improve cooking operations by sharing order information smoothly among staff [11][12][13]. Moreover, the restaurant industry has introduced cooking machines such as steam convection and sushi-cooking devices to improve cooking capacity at restaurant stores [14]. Recently, restaurants have started to introduce simulation systems to improve the kitchen layout [15][16].

Although the restaurant industry has introduced some systems and methodologies, Japanese cuisine restaurants have not changed traditional cooking systems. The cooking system of Japanese restaurants is similar to line production systems in manufacturing enterprises. Cooking equipment such as fryers, steamers, grills, and ovens are placed separately in the kitchen, and kitchen staff are placed and work separately in front of cooking equipment. When a restaurant is rushed, the production system functions smoothly because the kitchen staff members prepare the same kinds of dishes in bulk. However, the production system does not work well when a restaurant is not busy. While a restaurant is not busy, customers come to the restaurant and order in small numbers. Although the orders are few, cooking staff must be placed specifically in front of cooking equipment.

In addition, customs of Japanese chefs prevent restaurants from improving cooking operations. Traditionally, they do not prefer mutual support in the kitchen because of their pride. They believe that if a chef is supported by another chef, then is the former must be regarded as "less-skilled". As a result, workers labor separately even if the restaurant is not busy. Consequently, a restaurant can not adjust labor sales hours according to fluctuations. To improve labor productivity, restaurants should introduce a new production system and change the chef's consciousness about mutual assistance.

For this study, we introduce a "cell-production system" for a multiple Japanese cuisine restaurant to adjust labor hours related to fluctuation of sales revenues. To introduce it, we educate kitchen staff to make a change "from pride to cooperation". We measured sales per labor hour, and calculated the correlation of sales and labor hours as the KPI of labor productivity and elasticity of labor hour.

\section{Introducing the cell production system to a restaurant preparing Japanese cuisine}

A cell production system is introduced at Japanese restaurant A in Kyoto, operated by Ganko Food Service Co. Ltd. (Osaka, Japan). The restaurant has 250 tatami mat area on two floors, where 100 staff work (70 service staff; 30 kitchen staff). There are 10 positions in the restaurant kitchen: Washer, Salad, Sushi $\times 2$, Sashimi, Grill, Boil, Fryer, Noodle, and Set-up / Fig. 1).

Before the cell system was introduced, differences, characteristics, and strong and weak points of both line and production systems were introduced to the store manager and the master chef. A means to introduce a cell production system to the restaurant 
was discussed. The discussion concluded that chefs should be trained for mutual cooperation, before a cell production system could be introduced.

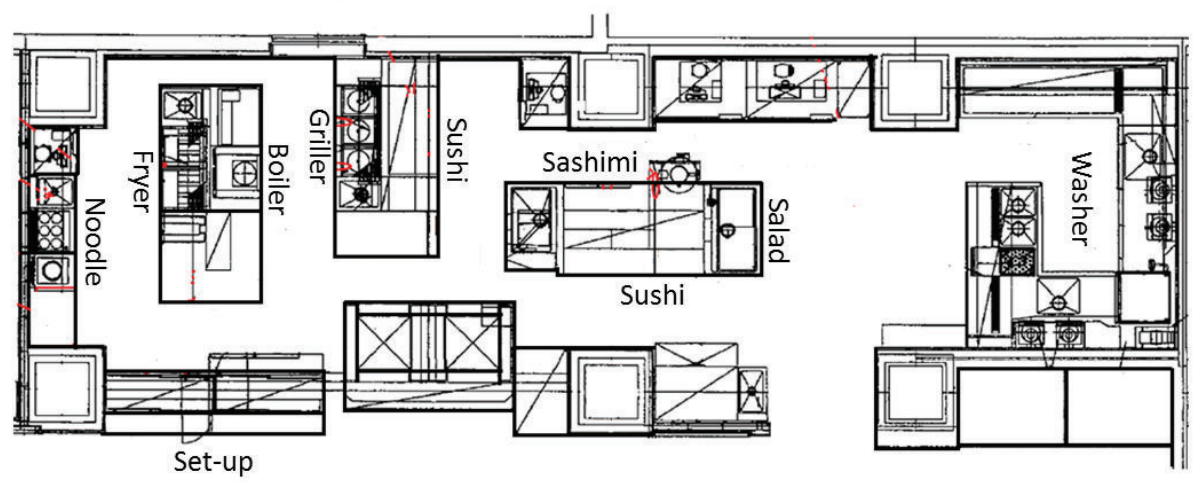

Fig. 1: Layout of restaurant A's kitchen.

To change cooking behavior, kitchen staff members were briefed on important aspects of the cell production system. They were also trained to change their conventional work customs. After explanation, the master chef changed work-scheduling and work-shift kitchen to support mutual cooperation for 2 months. To promote cooperation, observers checked kitchen operations and gave advice to the master chef to improve different points. When the restaurant is rushed, kitchen staff members work separately at individual cooking appliances. When restaurant demands are light, a kitchen staff cooks a plural genre of dishes using plural cooking appliances to reduce labor hours of idle time.

Two months later, cell cooking positions were introduced to restaurant A. Figure 2 shows the cell location at the restaurant A kitchen. Figure 3 shows placement of cooking equipment of the cell. When the restaurant is rushed, kitchen staff members work separately at individual cooking appliances. When the restaurant demands are light, a kitchen staff member cooks all kinds of dishes at a cell cooking position. The cell production system was operated for 2 months.

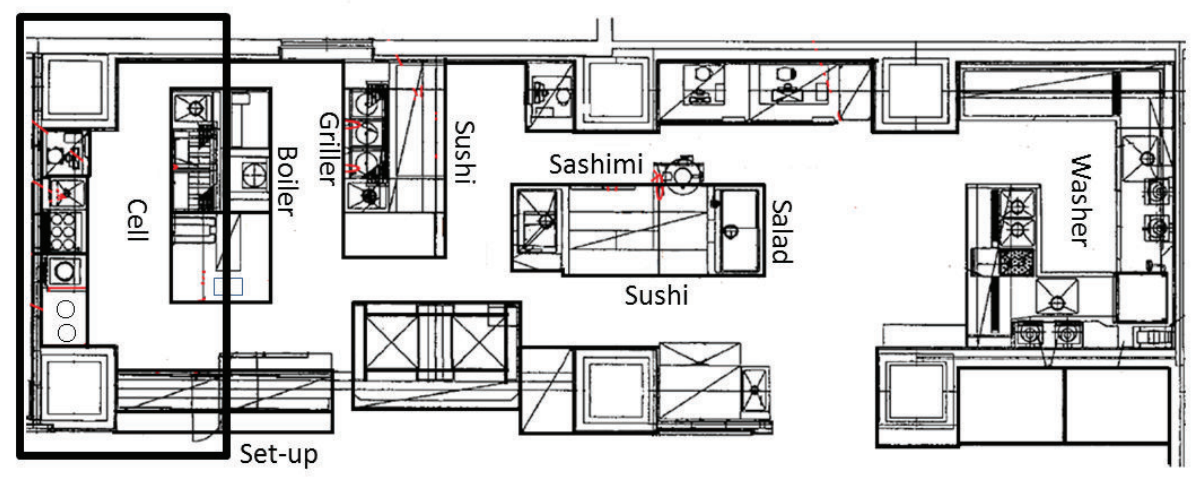

Fig. 2: Location of the cell at restaurant A's kitchen. 


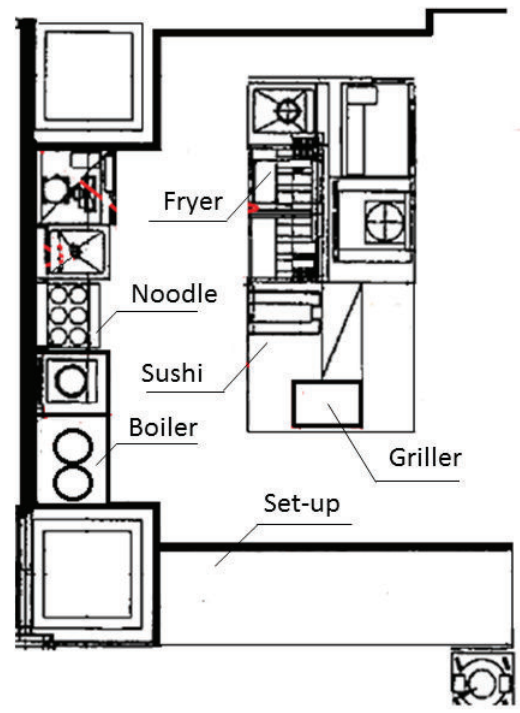

Fig. 3: Layout of cell at restaurant A.

After the experiment, revenue data and labor hour data (Before the experiment, for 2 months / after introducing a cell, for 2 months) are downloaded from the POS system and a labor control system. Sales per labor hour and correlation of sales and labor hours were calculated to confirm the availability of the cell production system for improvement of labor productivity and elasticity of labor hours.

\section{Results and discussion}

\subsection{Results}

Before the experiment (for 2 months), average sales per labor hour were 1,707k yen $(\mathrm{SD}=347 \mathrm{k}$ yen$)$, average labor hours were $137.3 \mathrm{hr}(\mathrm{SD}=16.2 \mathrm{hr})$, and the coefficient of correlation was 0.44 (Fig. 4-1). After introducing the cell production system (for 2 months), average sales per labor-hour were $1,661 \mathrm{k}$ yen $(\mathrm{SD}=304 \mathrm{k}$ yen), average labor hours were $116.0 \mathrm{hr}(\mathrm{SD}=12.2 \mathrm{hr}$ ), and the coefficient of correlation was 0.69 (Fig. 42). Relevant figures are presented on the next page. 


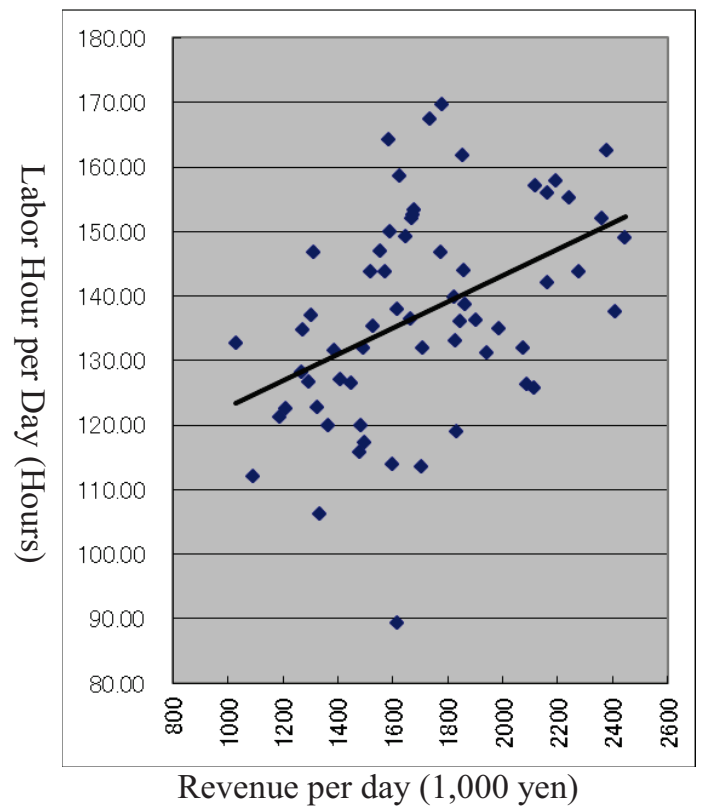

Fig. 4-1: Scatter diagram of revenue and labor hours (before experiment).

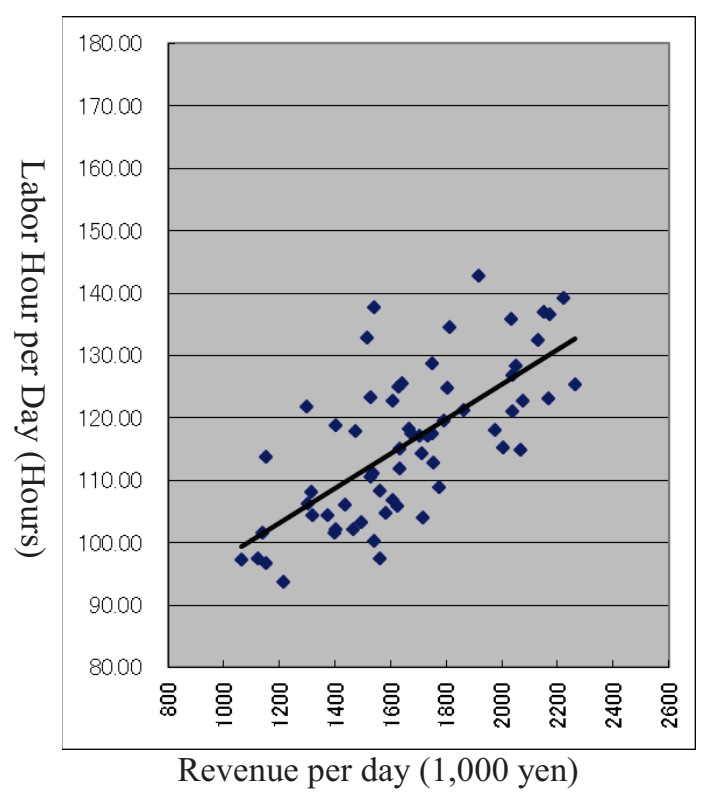

Fig. 4-2: Scatter diagram of revenue and labor hours (after introducing cell). 


\subsection{Discussions}

First, the cell production system efficacy for labor productivity improvement is discussed. Results show that labor hours of the restaurant were reduced from $137.3 \mathrm{hr}$ to $116.0 \mathrm{hr}$. The cell production system reduces $21.3 \mathrm{hr}(15.5 \%)$. Presumably, improved labor productivity occurred because sales revenues of both the pre-experiment and after introducing cell do not change so. Before the experiment, cooking staff work separately even if the restaurant is idle because of the kitchen layout. As Figure 1 shows, cooking equipment is placed discretely. The area is too broad to be crewed by one or even a few kitchen staff members if a full menu of products is to be provided.

The cell production system arranges all kinds of cooking appliances compactly (Fig. 3 ). When the restaurant is not busy, a kitchen staff member can prepare all kinds of dishes using cooking appliances situated in the cell. It is difficult to operate a cell production system if kitchen staff members are single-trained workers, as at a chain store. By contrast, multiple Japanese cuisine restaurants hire many "Syokunin" (crosstrained workers) who can prepare almost any dish, and it is easy to introduce a cell production system if they change their custom of avoiding mutual cooperation. This experiment trained staff ahead of introducing a cell production system. The training process promotes cooperation, and facilitates introduction of the cell production system.

Second, the elasticity of labor hours for sales revenue shows interesting results. The coefficient of correlation improved from 0.44 to 0.69 . Figure $4-1$ shows that restaurants require at least $110 \mathrm{hrs}$ to operate the kitchen before experiments. However, the restaurant requires less than about $100 \mathrm{hr}$ to operate because of introduction of the cell production system. The lower limit of kitchen staff was 3 before the experiment. However, that of the cell production system is 1 . Reduction of fixed-work hours promotes labor hour elasticity at the restaurant.

\section{Conclusions}

The study was conducted to improve labor productivity and elasticity of labor hours on sales revenue by introducing a cell production system at a multiproduct Japanese cuisine restaurant. Results shows that cell production systems improve operations: when the restaurant is not busy, a staff member can prepare any dish using cooking appliances situated in the cell. The system reduces fixed-labor hours at idle time, and it promotes a flexible work shift. To realize this system, kitchen staff should be trained to provide mutual support: conventionally, they dislike mutual cooperation because expressing a need for assistance implies inferior skills.

\section{Acknowledgements}

This study was partially supported by the project of service science from JST/RISTEX for Service Science in 2013, and joint study with Center for Service Research, National Institute of Advanced Industrial Science and Technology (AIST). 


\section{References}

1 Japanese Ministry of General Affairs and Communications, The Statistics Bureau and the Director-General for Policy Planning of Japan, Retrieved March 04, 2013, from http://www.stat.go.jp/english/index.htm

2 Takenaka, T., Shimmura. T., Ishigaki, T., Motomura. Y., Ohura. S.: Process management in restaurant service - a case study of Japanese restaurant chain-, Proceeding of International Symposium on Scheduling, 191-194 (2011)

3 Shimmura, T., Takenaka, T., Akamatsu M.: Improvement of restaurant operation by sharing order and customer information, International Journal of Organization and Collecting Intelligence, 1(3), 54-70 (2010)

4 Lovelock, C. H., Wirtz, J.: Service Marketing: People, Technology, Strategy, Seventh edition, Prentice Hall (2011)

5 Sako, M.: Outsourcing and offshoring: Implications for productivity of business services. Oxford Review of Economic Policy, 22(4), 499-512 (2006)

6 Pine, B, J, II ., Gilmore, J, H.: Welcome to the experience economy, Harvard Business Review, 76(4), 97-105 (1998)

7 Mefford, R. N.: Improving service quality: learning from manufacturing, International Journal of Production Economics, 30-31, 399-413 (1993)

8 Muller, C. C.: The business of restaurants: 2001 and beyond, International Journal of Hospitality Management, 18(4), 401-413 (1999)

9 Mariani, J. F.: America eats out: an Illustrated history of Restaurants, Taverns, Coffee shops, Speakeasies, and other Establishments that have Fed us for 350 Years, William Morrow and Co. (1991)

10 Chase, R. B., Apte, U. M.: History of research of service operations: What's the big idea?, Journal of Operations Management, 25, 375-386 (2007)

11 Swart, W.: A microcomputer network to enhance restaurant productivity, Computers \& Industrial Engineering, 11 (1), 430-433 (1986)

12 Stein, K.: Point-of-sales systems for foodservice, Journal of the American Dietetic Association, 105(12), 1861-1863 (2005)

13 Shimmura, T., Takenaka, T., Akamatsu, M.: Real-time process management system in a restaurant by sharing food order information, Proceeding of International Conference on Soft Computing and Pattern Recognition, 703-706 (2009)

14 Ngai, E, W, T., Suk, F, F, C., and S. Lo, S, S, Y.: Development of an RFIDbased sushi management system: the case of a conveyor-belt sushi restaurant, International Journal of Production Economics, 112(2), 630-645 (2008)

15 Brann, D. M., Kulick, B. C.: Simulation of restaurant operations using the restaurant modeling studio. New York: IEEE. (2002)

16 Sill, B.: Operations engineering: improving multiunit operations, The Cornell Hotel and Restaurant Administration Quarterly, 35(3), 64-71 (1994) 